\title{
ANALISIS KEMAMPUAN BERPIKIR KRITIS SISWA DALAM PEMBELAJARAN BIOLOGI
}

\author{
Desi Nuzul Agnafia \\ Pendidikan IPA, STKIP Modern Ngawi \\ email: desiagnaf@gmail.com
}

Diterima 30 Maret 2019 disetujui 7 Mei 2019

\begin{abstract}
The purpose of this research are to analyze the critical thinking ability of XA grade student at SMK BIM Ngawi. This research is include of descriptive qualitative research. The subject of research is XA grade at SMK BIM Ngawi. The technique sampling is purposive samping. The technique that use to fix the data is essay written test that developed by critical thinking ability indicator, based on Facione opinion. Based on data analysis critical thinking ability is gotten average explanation score $72 \%$ high category, interpretation $63 \%$ high category, analysis $31 \%$ low category, self regulation $51 \%$ category enough, evaluation $46 \%$ category enough and inferation $62 \%$ high category. The results or research show that almost the students critical thinking ability category enough. That result give an information to the teacher to train the criical thinking ability so can improve the students critical thinking ability more.
\end{abstract}

Keyword: Analysis, Critical Thinking Ability.

\section{PENDAHULUAN}

Perkebangan era globalisasi dan ilmu pengetahuan teknologi yang smakin mau dan modern akan menimbulkan dampak terhadap smua sektor kehidupan. Dalam menghadapi abad 21 ilmu pengetahuan dan teknologi merupakan salah satu bagian dari pendidikan yang menjadi pedoman yang harus disiapkan agar dapat mencetak manusia yang bermutu. Kompetensi yang harus dikuasi untuk menghadapi persaingan global dalam dunia kerja abad 21 adalah individu yang kreatif, berpikir kritis, mandiri, bekerja sama dengan tim, kreatifitas, informasi, komunikasi dan keamndirian belajar (Kivunja, 2015). Jaman yang semakin modern menuntut sumber daya manusia yang bermutu tinggi dan bidang pendidikan harus mempersiapkan diri dalam menghadapinya (Liliasari, 2011). Ketrampilan tingkat tinggi juga merupakan salah satu keahlian yang harus dipersiapkan oleh siswa dalam mencetak sumber daya manusia yang berkualitas. Berpikir ktitis merupakan salah satu bagian dari berpikir tingkat tinggi.

Siswa harus memiliki kemampuan berpikir kritis sebagai bekal utama dalam mempersipkan perubahan jaman yang smakin modern dan berkembang. Berpikir merupakan proses pikiran dalam mengadakan tanya jawab dalam menghubungkan pengetahuan dengan tepat. Proses mengolah, memanipulasi dan tranformasi informasi akan terjadi saat berpikir (Santrock, 2008). Berpikir kritis merupakan kemampuan kognitif dalam menentapkan suatu keputusan atau kesimpulan berdasarkan alasan logis dan disertai bukti yang empiris (Yaumi, 2012). Kesimpulan yang di lakukan sesuai dengan penilaian berdasarkan bukti empiris.

Pembelajaran biologi merupakan bagian dari sains yang mencakupfakta hukum dan prinsip hasil proses ilmiah yang memerlukan pemecahan masalah melalui kemampuan berpikir kritis. Cheong dan Cheung (2008) menjelaskan 
bahwa berpikir kritis memiliki peran penting dalam mempersiapkan siswa dalam memecahkan masalah, menjelaskan alasan serta membuat evaluasi informasi. Keterampilan sains dapat diasah melalui kemampuan berpikir kritis dan berproses dalam menemukan konsep baru dari kegiatan belajar (Liliasari, 2011).

Berpikir kritis merupakan kemampuan dalam menganalisis situasi yang yang didasrkan fakta, bukti sehingga dipeoleh suatu kesimpulan. Berpikir kritis juga meruapakan kemampuan dalam mengembangkan serta menjelaskan argumen dari data yang disusun menjadi suatu keputusan atau ide yang kompleks (Shriner, 2006). Pemikir kritis mampu menganalisis data atau informasi dengan cara yang tersusun sistematis berdasarkan logika dalam menyelidiki sebuah data atau fakta, selama ini pemikir kritis tidak begitu saja menerima pernyataan yang benar karena orang menganggap kebenarnanya pernyataan tersebut (Hendra, 2013). Kemampuan berpikir kritis merupakan kecakapam dalam berpikir reflektif serta memiliki alasan pada sesuatu yang dipercaya.

Kemampuan berpikir kritis di Indonesia berdasarkan Programme for International Student Assesment (PIZA) terlihat masih rendah. Ditunjukkan dari data tahun 2015 dengan skor 397 masih menduduki urutan ke- 62 dengan total peserta 72 negara, sedangkan data pada tahun 2012 dengan skor 396. Kemampuan berpikir kritis juga rendah terlihat dari data yang diteliti oleh Handriani (2015) di Mataram, Liberna (2014) di Jakarta, dan Hayudiyani di Madura.(2017).

Berdasarkan hasil wawancara dan observasi guru biologi dan siswa di SMK BIM Ngawi diperoleh hasil bahwa kriteria ketuntasan minimum masih belum tuntas ditunjukkan dengan adanya nilai ulangan harian, nilai ulangan umum yang banyak mendapatkan nilai dibawah KKM. Nilai KKM biologi di SMK BIM Ngawi adalah 75, jadi masih banyak siswa yang nilanya di bawah 75 . Jika nilai siswa 75 atau lebih dari itu siswa sudah tuntas atau memenuhi kriteria KKM. Siswa mengatakan bahwa dalam pelajaran biologi kurang optimal dalam mempelajarinya dikarenakan kurangnya pemahan siswa terhadap materi yang disampaikan.

Hasil belajar dari nilai diatas KKM tersebut menggambarkan seorang siswa telah berhasil dalam proses belajarnya. Dalam mencapai hasil belajar yang optimal perlu dibekali wawasan dalam berpikir yang logis dan kritis untuk mencapai tujuan pembelajaran (Hallatu, 2017). Pendidikan memiliki tujuan yaitu salah satunya untuk mengembangkan kemampuan berpikir kritis (Kazempour, 2013).

Pengukuran kemampuan berpikir kritis dengan menggunakan penjabaran indikator yang terdiri dari eksplanasi, interpretasi, analisis, evaluasi, inferensi, dan regulasi diri. Eksplanasi merupakan kemampuan dalam memberikan argumen dan menetapkannya secara logis berdasarkan data atau fakta yang diperoleh. Interpretasi adalah kemampuan dalam menafsirkan dan memahami makna dalam suatu masalah. Analisis adalah kemampuan dalam menyelidiki atau mengidentifikasi keterkaitan antara pernyataan, fakta data, konsep dan dapat menyimpulkannya. Evaluasi adalah kemampuan dalam menilai kredibilitas suatu pernyataan atau reprsentasi serta mengakses hubungan penyataan, data, fakta, konsep atau bentuk lainnya. Inferensi adalah kemampuan dalam mengdentifikasi dan mendapatkan konsep atau unsur dalam dalam menarik suatu kesimpulan. Regulasi diri adalah kemampuan memonitor dirinya sendiri dalam 
mengaplikasikan menganalisis dan mengevaluasi dari hasil berpikir sebelumnya dalam menyelesaikan suatu masalah. Indikator keterampilan berpikir kritis menurut Facione diuraikan menjadi sub indikator yang dijabarkan ke dalam tabel 1 .

Tabel 1. Indikator dan sub indikator kemampiuan berpikir kritis.

\begin{tabular}{ll}
\hline Indikator & Sub Indikator \\
\hline Interpretasi & Mengkategorikan \\
& Mengkodekan \\
Analisis & Meklasifikasikan \\
& Memeriksa ide \\
Inferensi & Menilai argumen \\
& Mempertanyakan bukti \\
& Memprediksi Alternatif \\
& Mengambil \\
Eksplanasi & keputusan/kesimpulan \\
& Menyatakan hasil \\
& Membenarkan prosedur \\
& Memaparkan argumen \\
Pengaturan & Mengokteksi diri \\
Diri & Pengkajian dirinya \\
& Mengoreksi dirinya \\
\hline
\end{tabular}

Penelitian yang dilakukan ini menggunakan indikator tersebut sebagai instrumen pengukuran berpikir kritis. Penelitian yang dilakukan ini bertujuan untuk menganalisis sebuah kemampuan berpikir kritis siswa. Penelitian ini perlu dilakukan sebagai masukan bagi guru dan pihak lainnya agar dapat mengembangkan kemampuan berpikir kritis dan merancang proses pembelajarannya. Salah satu penentu keberhasilan dalam belajar adalah guru. Guru harus memiliki inovasi dalam pendidikan. Sehingga diharapkan dapat menghasilkan sumber daya yang berkualitas.

\section{METODE}

Jenis penelitian yang dilakukan ini adalah penelitian berbentuk deskriptif kualitatif yaitu suatu penelitian untuk menggali data kondisi yang sebenarnya. Arikunto (2013) menyatakan bahwa penelitian deskriptif menjelaskan suatu kondisi yang terjadi sebenanrnya, tidak ada penambahan variabel bebas serta tidak ada manipulasi sehingga menggambarkan situasi yang sebenarnya. Tingkat kemampuan berpikir kritis siswa dapat diketahui dengan menggunakan indikator yang telah ditetapkan.

Kemampuan berpikir kritis siswa dapat diketahui hasilnya dengan melakukan penelitian ini. Kelas X SMK BIM Ngawi adalah subjek pnelitian ini. Sampel penelitian terdiri dari kelas X A sejumlah 24. Penentuan informan menggunakan prosedur purposive yaitu Sugiyono (2009) menjelaskan bahwa purposive menggunakan teknik pemilihan dengan suatu maksud tertentu dan berdasrkan pertimbangan tertentu.

Tahapan dalam penelitian ini terdiri dari tahapan awal, tahapan inti dan tahapan akhir. Observasi, rancangan penelitian, dan penyususnan instrumen merupakan bagian dari tahap awal.Tahap inti kegiatan yang dilakukan yaitu menguji siswa dengan memberikan tes tulis essay berupa soal yang mengandung kemampuan dalam berpikir kritis pada mata pelajaran biologi materi virus. Tahap akhir menganalisis data yang diperoleh sesuai dengan metode analisis kemudian membuat kesimpulan dari data tersebut. Berdasarkan data hasil penelitian selanjutnya akan disusun laporan.

Tes tulis essai yang digunakan sebagai teknik pengumpulan data dalam penelitian ini. Tes tulis dilaksanakan oleh siswa sampel penelitian dengan tujuan mengetahui kemampuan siswa dalam berpikir kritis. Instrumen penelitian yang digunakan adalah soal essay besertai 
rublik penilaian sebagai pedoman penskoran. Soal terdiri dari aspek kemampuan siswa dalam berpikir kritis yang dikembangakan dari pendapat Facione (2010). Kemampuan siswa dalam berpikir kritis yang diukur terdiri atas: interpretasi, analisis, inferensi, evaluasi, eksplanasi dan pengaturan diri. Tes esay tersusun dari 6 buah soal yang berisi stiap soalnya tentang indikator indikator berpikir kritis. Hasil dari tes kemampuan dalam berpikir kritis yang dilaksanakan oleh siswa akan diperoleh berdasarkan rubrik penilaian sebagai penentuan siswa apakah sudah terpenuhi atau belum kriteria indikator berpikir kritis. Hasil data akan disajikan dalam bentuk skor presentase.

\section{HASIL DAN PEMBAHASAN}

Berdasarkan analisis data diperoleh hasil bahwa rata-rata hasil tes kemampuan berpikir kritis siwa kelas XA SMK BIM Ngawi dalam tingkat kategori sedang dan perlu ditingkatkan lagi. Hasil ini sesuai dengan penelitian yang dilakukan oleh Shanti (2017) bahwa siswa masih kurang dalam kemampuannya untuk berpikir kritis dan perlu peningkatan lagi. Sebagian besar siswa bingung dalam menerapkan konsep pengetahuan yang dimilikinya dalam menyelesaikan masalah.

Kemampuan berpikir kritis siswa kurang optimal dikarenakan pembelajaran yang dilakukan masih belum memberdayakan kemampuan berpikir kritis. Siswa lebih sering menghapal dalam belajar biologi. Kurangnya latihan dan aktivitas dalam berpikir kritis juga menjadi penyebab bahwa kemampuan berpikir kritis siwa rendah yaitu ditunjukkan dengan soal ujian yang di terapkan pada siswa masih bersifat hafalan dan ingatan. Sejalan yang diungkapkan oleh Snyder \& Snyder (2008) bahwa siswa tidak dapat menyelesaikan masalah karena kurangnya kemampuan berpikir kritis, siswa terlalu banyak menghapal yang membuat siswa sedikit berpikir dan sedikit penguasaan konsep. Jika siswa sering dilatih dalam aktivitas berpikir kritis maka kemampuan berpikir kritis siswa dapat berkembang optimal. Muhfayorin(2009) juga menyatakan bahwa pelatihan kemampuan berpikir kritis siswa yang dilakukan dengan baik akan meningkatkan minat belajar siswa dan percaya diri dalam memecahkan masalah sehingga hasil belajar juga maksimal.

Kemampuan berpikir siswa di Indonesia masih rendah ditunjukkan dari fakta di lapangan bahwa pada penelitian Liberna (2014) di Jakarta, Rahma (2012) di Semarang. Berdasarkan hasil dilapangan hasil kemampuan berpikir kritis siswa diperoleh dari tes soal uraian kemampuan siswa dalam berpikir kritis yang mengacu pada indikator menurut Facione (2010). Analisis data kemampuan dalam berpikir kritis siswadiketahui dari hasil tes essai. Hasil data yang diperoleh dari penelitian dianalisis berdasarkan persentase kriteria pencapaian kemampuan berpikir kritis menurut Riduwan (2013).

Kriteria pengelompokkan berpikir kritis terdiri skor sangat tinggi, tinggi, cukup atau sedang, rendah dan sangat rendah. Kriteria dalam mengkategorikan kemampuan berpikir kritis dapat dilihat pada Tabel 2.

Tabel 2. Kriteria tingkat Kemampuan Berpikir Kritis siswa

\begin{tabular}{lll}
\hline No & Presentase & Kategori \\
\hline 1 & $81-100$ & Sangat Tinggi \\
2 & $61-80$ & Tinggi \\
3 & $41-60$ & Cukup \\
4 & $21-40$ & Rendah \\
5 & $0-20$ & Rendah Sekali \\
\hline & & (Riduwan, 2013)
\end{tabular}


Hasil tes kemampuan berpikir kritis siswa dianalisis per indikatornya yang terdiri dari 6 soal esay dengan indkator yang terdiri yaitu eksplanasi, intepretasi, analisis, regulasi diri, evaluasi dan inferensi. Setiap siswa dianalisis kemampuan berpikir kritis dengan materi virus, dimana setiap nomor memiliki point skor sesuai indikatornya dengan jumlah total skor 100. Soal eksplanasi skor 10 , intepretasi skor 15 , analisis skor 20 , regulasi diri skor 25 , evaluasi skor 25 , dan inferensi skor 5. Distribusi frekuensi hasil tes kemampuan dalam berpikir kritis pada siswa ditunjukan pada Tabel . 3 .

Tabel 3. Distribusi frekuensi hasil tes kemampuan berpikir kritis siswa

\begin{tabular}{cc}
\hline Rentang perolehan skor & Frekuensi \\
\hline $20-40$ & 6 \\
$41-60$ & 11 \\
$61-80$ & 5 \\
$81-100$ & 0 \\
\hline
\end{tabular}

Berdasarkan data pada Tabel. 3 diperoleh hasil dari tes essay dengan 6 soal yang dikembangkan sesuai indikator kemampuan siswa dalam berpikir kritis. Setiap siswa memperoleh skor penilaian dengan nilai tertinggi 65 dan nilai terendah 35. Berdasarkan hasil analisis yang dilakukan dapat ditunjukkan bahwa tingkat kemampuan dalam berpikir kritis pada siswa dalam tingkat sedang. Siswa yang dikategorikan ke dalam berpikir kritis sangat tinggi belum ada. Sedangkan siswa yang memperoleh hasil tingkat berpikir kritis baik sejumlah 6 siswa. Siswa yang memperoleh hasil tingkat kemampuan dalam berpikir kritis kategori sedang sejumlah 11 siswa. Meskipun demikian masih ada siswa yang meiliki skor dibawah 40 yaitu 6 anak dimana dikategorikan ke dalam tingkatan kemamampuan dalam berpikir kritis rendah. Hasil rata rata dari kemampuan dalam berpikir kritius siswa dianalisis berdasarkan per indikator kemampuan berpikir kritis yang ditunjukkan pada tabel 4.

Tabel 4. Rata-rata presentase skor indikator kemampuan berpikir kritis siswa

\begin{tabular}{lll}
\hline \multicolumn{1}{c}{$\begin{array}{c}\text { Indikator } \\
\text { KBK }\end{array}$} & $\begin{array}{c}\text { Presentase } \\
\text { skor }\end{array}$ & Kategori \\
\hline Eksplanasi & $72 \%$ & Tinggi \\
Intepretasi & $63 \%$ & Tinggi \\
Analisis & $31 \%$ & Rendah \\
Regulasi Diri & $51 \%$ & Cukup \\
Evaluasi & $46 \%$ & Cukup \\
Inferensi & $62 \%$ & Tinggi \\
\hline
\end{tabular}

Terdapat perbedaan hasil setiap presentase indikator kemampuan dalam berpikir kritis siswa yang dijabarkan pada tabel 4. Indikator eskplanasi menghasilkan presentase skor yang tertinggi daripada indikator yang lainnya dengan perolehan sebesar $72 \%$ dengan kriteria kemampuan berpikir kritis kategori tinggi. Presentase skor tinggi lainnya adalah indikator intepretasi sebesar 63\% dengan kriteria kemampuan berpikir kritis kategori tinggi. Indikator Inferensi juga memperoleh hasil berpikir kritis kategori tinggi yaitu sebsesar $62 \%$. Kategori kemampuan berpikir kritis sedang atau cukup yaitu regulasi diri dengan skor $51 \%$ dan evaluasi diri $46 \%$. Kemampuan berpikir kritis dengan nilai paling rendah adalah indikator analisis dengan perolehan skor $31 \%$ yang dikategorikan kedalam kemampuan berpikir kritis buruk. Perbandingan diagram hasil presentase skor per indikator kemampuan dalam berpikir kritis dapat dilihat pada Gambar 1. Hasil pada Tabel 3 dan Gambar 1 diperoleh dari hasil analisis indikator dalam kemampuan berpikir kritis yaitu (1) eksplanasi, (2) interpretasi, (3) analisis, (4) regulasi diri, (5) evaluasi, dan (6) inferensi. Tingkat kemampuan berpikir kritis yang menduduki urutan paling rendah adalah indikator analisis. Siswa masih kurang bisa menyelesaikan 
masalah dengan menganalisis. Siswa masih belum bisa menyelesaikan pemecahan masalah dengan teknik yang tepat. Indikator eksplanasi, intepretasi, dan inferensi memperoleh hasil kemampuan berpikir kritis baik. Tiga indikator ini pada dasarnya sudah dipenuhi oleh siswa dalam dalam kemampuannya untuk berpikir kritis.

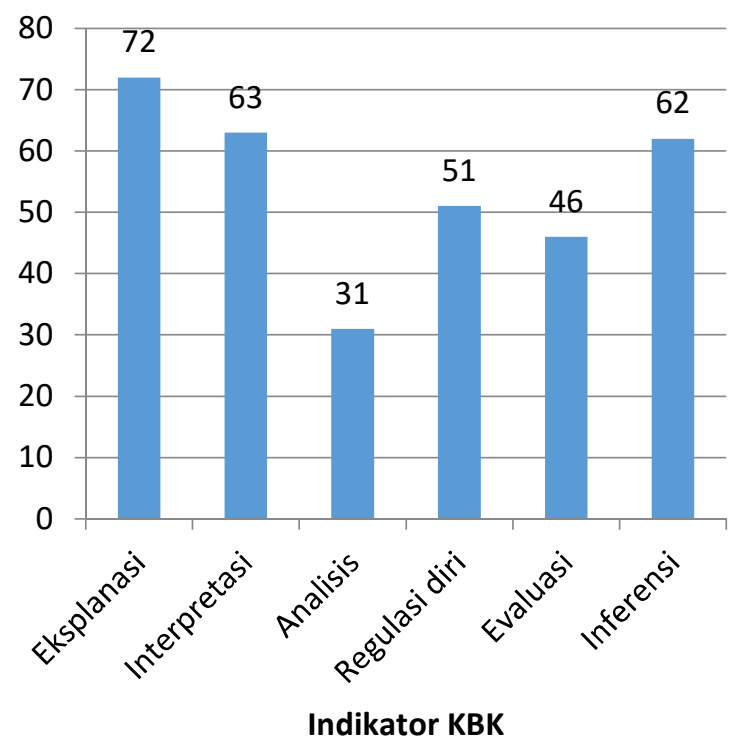

Gambar 1. Rata-rata presentase skor indikator kemampuan berpikir kritis siswa

Indikator eksplanasi merupakan kemampuan siswa dalam menjelaskan atau membuat keterangan mengenai sebab akibat dari masalah. Indikator eksplanasi siswa mampu menjelaskan pernyataan atau pendapat yang di sampaikan sehingga tersusun menjadi sebuah pendapat yang kuat. Eksplanasi merupakan kemampuan siswa untuk mengemukakan hasil dari data, bukti, pendapat, atau pertanyaan. Indikator ini sudah biasa dilaksanakan oleh siswa sehingga hasil perolehhan skor dalam kategori baik Pemecahan masalah dalam menjawab indikator eksplanasi ditingkatkan wawasan atau pengetahuan melalui membaca, pengamatan dan diskusi. Hal ini selalu dilatihkan oleh guru sehingga siswa sudah terbiasa dalam memecahkan persoalan yang berhubungan dengan eksplanasi. Melalui eksplanasi dapat melatih siswa dalam mengembangkan penalaran serta berpikir kritis siswa (Pujiono, 2012).

Indikator interpretasi diperoleh perentase skor $63 \%$ dengan kategori baik. Intepretasi berkaitan dengan kemampuan siswa dalam memaknai dan menguraikan obyek yang diamati. Intepretasi melatihkan siswa dalam menjelaskan kembali serta memahami makna dari suatu peristiwa, data, prosedur atau aturan. Siswa memberikan umpan balikan dan mengungkapkan kembali pada pengamatan suatu obyek. Salah satu bagian pentng dalam berpikir kritis yang harus dipelajari siswa agar dapat memiliki kemampuan berpikir kritis adalah membuat interpretasi (Orlich, 2010). Pengukuran indikator interpretasi dengan menyajikan gambar struktur tubuh salah satu virus. Siswa sudah mampu mendeskripsikan gambar serta mengkategorikan klasifikasi dari virus.

Indikator analisis diperoleh skor $31 \%$ sehingga dapat disimpulkan bahwa kemampuan berpikir kritis pada indikator ini dalam kategori rendah. Skor yang rendah pada indikator analisis disebabkan karena siswa belum mampu mengidentifikasi keterkaitan konsep dan aktual dari pernyataan atau pertanyaan. Siswa masih jarang dilatihkan indikator analisis. Siswa harus mampu menguji ide dan mengungkapkan alasan maupun pernyataan. Siswa belum bisa menganalisis suatu masalah dan memilih strategi yang tepat dalam menyelesaikan masalah tersebut. Pengukuran indikator analisis dihadapkan dalam menyelesaikan masalah tentang proses reproduksi virus. Siswa masih terlihat bingung dalam menganalisis perbedaan siklus beserta tahapan reproduksinya.

Indikator regulasi diri diperoleh presentase skor $51 \%$ dengan kategori cukup atau sedang. Masalah yang diselesaikan siswa pada indikator ini 
berkaitan dengan kemampuannya dalam mengatur keberadaan dirinya. Siswa dapat mengontrol dirinya dalam menghadapi permasalahan dengan menerapkan keahlian dalam menganalisa dan mengevaluasi hasil yang telah dikembangkan oleh dirinya. Pengukuran indikator ini siswa dihadapkan pada permasalah yang berhubungan dengan penyakit yang disebabkan virus. Penerapan terhadap pencegahan terhadap virus.

Indikator evaluasi diperoleh hasil presentase $46 \%$ dengan kategori cukup mampu berpikir kritis. Siswa cukup mampu membuat sebuah ikhtiar atau menyimpulkan dalam mengatasi sebuah permasalahan. Siswa cukup mampu menguji dan memperkirakan penalaran logis dari faka, data, deskripsi atau representasi. Siswa yang dapat berpikir kritis dapat melakukan evaluasi terhadap pikirannya serta membandingkan dengan data fakta pendapat serta pemikiran dari orang lain (Rugerio, 2012). Meskipun demikian masih kurang dari setengah jumlah siswa yang masih belum mampu memecahkan masalah padates indikator evaluasi. Setengah dari total siswa belum mampu mengambil keputusan serta mengemukakan alasannya dalam langkah pencegahan virus.

Indikator inferensi diperoleh skor presentase $62 \%$ dengan kategori mampu berpikir kritis dengan baik. Siswat secara umum mampu dalam menidentifikasi dan memecahkan suatu masalah sehingga menggambarkan suatu kesimpulan. Penarikan kesimpulan dilakukan untuk menfasirkan apa yang telah terjadi atau diamati (Koasih, 2014).

Siswa yang kurang mampu berpikir kritis dikarenakan dalam pembelajaran masih mengutamakan proses ingatan, dan

memahami. Siswa masih berfokus menghapal suatu konsep dalam pembelajaran dan konsep yang diperoleh hanya bersumber pada buku dan guru (Ritonga, 2013).

Kemampuan dalam berpikir kritis siswa yang tergolong kurang perlu ditingkatkan lagi dan di evaluasi kembali terhadap proses pembelajaran yang dilakukan, karena dengan proses pembelajaran yang sesuai kemampuan berpikir kritis dapat meningkat.

Kemampuan berpikir kritis dapat ditingkatkan dengan menerapkan startegi yang memiliki ciri meibatkan interkasi aktif dari siswa dan menggunakan kemampuan kognitifnya kognitifnya dalam mengaplikasikan konsep dan memecahkan masalah (Agboze\& Ugwoke, 2013). Kemampuan berpikir kritis juga dapat ditingkatkan dengan memberikan pertanyaan yang bersifat penyelidikan, menumbuhkan siswa untuk memecahkan masalah serta membuat kesimpulan berdasarkan penyelidikan (Iavokos, 2011)..

Pengembangan kemampuan berpikir kritis dilakukan oleh guru dengan melatihkan kemampuan berpikir kritis dan memfasilitasi dalam kegiatan pembelajaran dengan indikator indikator berpikir kritis. Pengembangan tersebut tidak hanya dilakukan oleh guru saja tetapi pemerintah telah berupaya dalam meningkatkan berpikir kritis melalui penerapan kurikulum 2013. Upaya lainnya yang dapat dilakukan adalah dengan melakukan pelatihan terhadap guru dalam meningkatkan kemampuan berpikir kritis dalam dunia pendidikan.

\section{SIMPULAN}

Berdasarkan hasil penelitian yang dilakukan dapat ditarik kesimpulan bahwa hasil dari analisis kemampuan siswa dalam berpikir kritis pada kelas XA SMK BIM Ngawi didapatkan presentase ketercapaian setiap indikator kemampaun berpikir kritis yaitu indikator eksplanasi sebesar $72 \%$, indikator interpretasi sebesar $63 \%$, indikator analisis sebesar 
$31 \%$, indikator regulasi diri sebesar 51\%, indikator evaluasi sebesar $46 \%$, dan indikator inferensi sebesar $62 \%$. Hasil dari penelitian ini dapat memberikan pemaparan tentang tingkat berpikir kritis kepada siswa, guru, dan pihak sekolah. Kemampuan berpikir kritis siwa yang masih kurang atau rendah disebabkan karena siswa belum biasa dilatihkan indikator indikator dari kemampuan dalam berpikir kritis, masih kurangnya pembelajaran yang diterapkan dalam memberdayakan kemampuan siswa untuk berpikir kritis. Guru lebih inovatif serta lebih kreatif dalam merancang proses pembelajaran terutama dalam mengembangkan kemampuan berpikir kritis siswa.

\section{DAFTAR PUSTAKA}

Agboeze, Matthias U and Ugwoke, Ernes. 2013. Enhancement of Critical Thinking Skills of Vocational and Adult Education Students for Entrepreneurship Development in Nigeria. Journal of Education and Practice. Vol.4 (17). ISSN 2222-1735 (Paper) ISSN 2222-288X (Online

Arikunto, S. (2013). Prosedur Penelitian: Suatu Pendekatan Praktik. Jakarta: Rineka cipta.

Cheong, C.M dan Cheung, W.S. 2008. Online Discusion and Critical Thingking Skills: A case study in a Singapore Secondary School. Australian Journal of Educational Technology. 24(5): 556-557

Ennis, Robert H. 2011. The Nature of Critical Thinking: An Outline of Critical Thinking Disposition and Abilities. Diakses pada http:// faculty.ed.uiuc.edu/rhennis.

Facione, N.C, \& Facione,P.A 2010. Externalizing, The Critical Thinking in Knowledge Development and Clinical Judgment. Nursing Outlook.
Hallatu, Y., Prasetyo, K. Haidar. A. (2017). Pengaruh Model Problem Based Learning Terhadap Kompetensi Pengetahuan dan Keterampilan Berpikir Kritis Siswa MA BPD Tentang Konflik. Jurnal Penelitian Pendidikan, 34 (2): 183190.

Handriani, Lia., Harjono, A., dan Doyan, A. (2015). Pengaruh Model Pembelajaran Inkuiri Terstruktur dengan Pendekatan Saintifik Terhadap Kemampuan Berpikir Kritis dan Hasil Belajar Fisika Siswa. Jurnal Pendidikan Fisika dan Teknologi, 1(3):210-219.

Hendra, S. (2013). Belajar Orang Genius. Jakarta: Gramedia

Hayudiyani, M., Arif, M., dan Risnasari, M. (2017). Identifikasi Kemampuan Berpikir Kritis Siswa Kelas X Tkj Ditinjau Dari Kemampuan Awal Dan Jenis Kelamin Siswa di SMKN 1 Kamal. Jurnal Ilmiah Edutic, 4(1) :20-31.

Iavokos, Tsiplakides. (2011). Critical and Creative Thinking in the English Language Classrom, International Journal of Humanities and Social Science. 1(8): 82-86.

Kazempour, E. (2013). The Effect of Inquiry Based Teaching on Critical Thinking of Students, Journal of Social Issues and Humanities. 1(3)23-27.

Kivunja, Charles. (2015). Teaching Students to Learn and to Work Well with 21 Century Skills: Unpacking the Career and Life Skills Domain of the New Learning Paradigm. International Journal of Higher Education. 4(1): 2-11.

Koasih, E. (2014). Strategi Belajar dan Pembelajaran. Bandung: Yrama Widya. 
Liberna, Hawa. 2014. Peningkatan Kemampuan Berpikir Kritis Matematis Siswa Melalui Penggunaan Metode Improve pada materi Sistem Persamaan Linear Dua Variabel. Jurnal Fomatif. 2(3): 190197.

Liliasari. (2011). Peningkatan Kualitas Guru Sains Melalui Pngembangan Keterampilan bERPIKIR Tingkat Tinggi. Seminar Nasional Pasca Sarjana. Bandung: UPI.

Muhfahroyin. (2009). Memberdayakan Kemampuan Berpikir Kritis Siswa Melalui Pembelajaran Kontruktivis. Jurnal Pendidikan dan Pembelajaran. 16(1).

Nur, M. (2013). Pendidikan dan Latihan Pembelajaran Inovatif dan Pengembangan Perangkat Pembelajaran Bermuatan Keterampilan Berpikir dan Perilaku Karakter. Kerjasama program studi Magister Pendidikan Biologi PPs Unlam dengan Pusat Sains dan Matematika UNESA.

Pujiono, Setyawan. (2012). Berpikir Kritis dalam Literasi membaca dan menulis untuk memperkuat jati diri bangsa, 778-783. UNSOED: Prosiding Bahasa dan Sastra Indonesia.

Rahma, A.N. 2012. Pengembangan Perangkat Pembelajaran Model Inkuiri Berpendekatan SETS Materi Kelarutan Dan Hasil Kali Kelarutan Untuk Menumbuhkan Keterampilan Berpikir Kritis dan Empati Siswa Terhadap Lingkungan.Journal of Educational Research and Evaluation. 2(2).

Riduwan. (2011). Dasar-Dasar Statistik. Bandung: Alfabeta.

Ritonga, G.A. 2013. Pengembangan Modul Pembelajaran Fisika Berorientasi Model Learning Cycle Pada Materi Listrik Dinamis Untuk SMA Kelas X.
Skripsi Tidak Dipublikasikan. Universitas Jambi

Ruggerio, V. R. (2012). Beyond Feelings: A Guide to Critical Thinking. New York: McGraw-Hill.

Santrock, John W. (2008). Psikologi Pendidikan. Jakarta: Prenada Media Group.

Shanti, Widha N. (2017). Meningkatkan Kemampuan Berpikir Kritis melalui Problem Posing, Literasi.8(1): 49-59.

Shriner, Mary. (2006). Critical Thinking in Higher Education: An Annotated Bibliography. Insight : A Collection of Faculty Scholarship. 1(206):5966.

Snyder, L.G dan Snyder, M.J. (2008). Teaching Critical Thinking and Problem Solving Skills. The Delta Epsilon Journal. L (2):90-99.

Sugiyono. (2009). Metode Peneltian Kuantitatif, Kualitatif dan $R \& D$. Bandung: Alfabeta.

Orlich, D. C. (2010). Teaching strategis a guide to effective instruction. Boston : Cengage Learning.

Yaumi, Muhammad. (2012). Pembelajaran Berbasis Multiple Intelligences. Jakarta: Dian Rakyat. 